\title{
Engineering Parameters in Bioreactor's Design: A Critical Aspect in Tissue Engineering
}

\author{
Nasim Salehi-Nik, ${ }^{1,2}$ Ghassem Amoabediny, ${ }^{1,2}$ Behdad Pouran,,2 Hadi Tabesh, ${ }^{3}$ \\ Mohammad Ali Shokrgozar, ${ }^{4}$ Nooshin Haghighipour, ${ }^{4}$ Nahid Khatibi, ${ }^{1,2}$ Fatemeh Anisi, ${ }^{1,2}$ \\ Khosrow Mottaghy, ${ }^{3}$ and Behrouz Zandieh-Doulabi ${ }^{5}$ \\ ${ }^{1}$ Department of Chemical Engineering, Faculty of Engineering, University of Tehran, P.O. Box 11365-4563, Tehran, Iran \\ ${ }^{2}$ Department of Biomedical Engineering, Research Center for New Technologies in Life Science Engineering, \\ University of Tehran, P.O. Box 14395-1374, Tehran, Iran \\ ${ }^{3}$ Institute of Physiology, Medical Faculty, RWTH Aachen University, 52074 Aachen, Germany \\ ${ }^{4}$ National Cell Bank, Pasteur Institute of Iran, P.O. Box 1316943551, Tehran, Iran \\ ${ }^{5}$ Gustav Mahlerlaan 3004, 1081 LA Amsterdam, The Netherlands
}

Correspondence should be addressed to Ghassem Amoabediny; amoabediny@ut.ac.ir

Received 9 April 2013; Revised 27 June 2013; Accepted 1 July 2013

Academic Editor: Kacey Gribbin Marra

Copyright (C) 2013 Nasim Salehi-Nik et al. This is an open access article distributed under the Creative Commons Attribution License, which permits unrestricted use, distribution, and reproduction in any medium, provided the original work is properly cited.

\begin{abstract}
Bioreactors are important inevitable part of any tissue engineering (TE) strategy as they aid the construction of three-dimensional functional tissues. Since the ultimate aim of a bioreactor is to create a biological product, the engineering parameters, for example, internal and external mass transfer, fluid velocity, shear stress, electrical current distribution, and so forth, are worth to be thoroughly investigated. The effects of such engineering parameters on biological cultures have been addressed in only a few preceding studies. Furthermore, it would be highly inefficient to determine the optimal engineering parameters by trial and error method. A solution is provided by emerging modeling and computational tools and by analyzing oxygen, carbon dioxide, and nutrient and metabolism waste material transports, which can simulate and predict the experimental results. Discovering the optimal engineering parameters is crucial not only to reduce the cost and time of experiments, but also to enhance efficacy and functionality of the tissue construct. This review intends to provide an inclusive package of the engineering parameters together with their calculation procedure in addition to the modeling techniques in TE bioreactors.
\end{abstract}

\section{Introduction}

Tissue engineering aims to generate three-dimensional (3D) artificial tissues. Its consequential task is to regenerate human tissue or develop cell-based substitutes for tissue in order to restore, reconstruct, or improve tissue functions $[1,2]$. Achieving biological and mechanical functionality of the newly formed tissue is paramount for tissue engineered structures. Yet current research often focusses on form rather than function. Regeneration of functional organs demands intensive researches and studies in every aspect of TE [3], since creating a functional tissue requires the efficient growth of various types of cells on a single $3 \mathrm{D}$ structure [2].
Bioreactors can aid the production of functional 3D tissues as follows: (1) by maintaining a desired uniform cell concentration within the scaffold during cell seeding, (2) by controlling microenvironmental parameters (e.g., temperature, $\mathrm{pH}$, pressure, oxygen tension, metabolites, regulatory molecules, shear stress, and electrical pacing) and aseptic parameters (e.g., feeding, waste removal, and sampling), (3) by facilitating mass transfer [4-7], and more importantly (4) by allowing for automated processing steps.

Moreover, each special type of tissue structure and production procedure (e.g., skin, bone, blood vessel, cartilage, and myocardium) necessitates a unique kind of bioreactor 
design which requires both biological and engineering conditions to be addressed along with reliability, reproducibility, scalability, and safety issues [8-10].

In this review, key technical challenges between biological parameters and engineering parameters are recognized along with an overview of present mathematical modeling and monitoring of tissue growth carried out in the Research Center for New Technologies in Life Science Engineering at University of Tehran (UTLSE) to help deal with ongoing challenges.

\section{Engineering Parameters in TE Bioreactor Design}

Generally, the major responsibilities of a bioreactor are to provide a biomechanical and a biochemical environment that controls nutrient and oxygen transfer to the cells and metabolic products from the cells [11-13]. Mass transfer problems (e.g., oxygen and nutrient supply and removal of toxic metabolites) must always be taken into account. The size of most engineered tissues is limited as they do not have their own blood system and the cells are only nourished by diffusion $[14,15]$. Since tissue constructions should have larger dimensions to become functional, mass transfer limitation can be considered as one of the greatest engineering challenges [1].

Moreover, biomechanical stimuli such as shear stress can be applied throughout the bioreactor by means of culture medium flow $[10,16]$. In this condition, nutrient and waste transfer are automatically regulated by the flow of the growth medium. Other types of mechanical stimuli can also be applied to tissue constructs using a bioreactor, including axial compression or tensile forces [11].

Although biomechanical stimuli have many advantages for tissue engineering, mechanical stimuli can also induce tissue degradation, by alterations in the synthesis of matrix [16]. All in all, the response of some types of cells to mechanical stress causes radical changes to the tissue structure and composition which leads to alterations in tissue functionality.

In the following section, some of the engineering parameters which help providing physical stimulation to TE constructs in order to enhance tissue formation and their concomitant challenges are specified.

2.1. Mass Transfer through Bioreactors. The major obstacle that hinders practical application of 3D cell seeded constructs is mass transfer [5]. After distributing cells throughout porous scaffolds, a key challenge is the maintenance of cell viability, especially within the interior of the construct during prolonged culture. Nutrients, oxygen, and regulatory molecules have to be efficiently transferred from the bulk culture medium to the tissue surfaces (i.e., external mass transfer) as well as to the interior cells of the tissue construct (i.e., internal mass transfer). In addition, metabolites and $\mathrm{CO}_{2}$ are to be removed from the cells within the tissue to the bulk medium. While external mass transfer rates depend primarily on hydrodynamic conditions in a bioreactor, internal mass transfer rates may depend on a combination of diffusion and convection mechanisms (typically induced by medium perfusion or scaffold deformation). Internal mass transfer depends strongly on the scaffold's structure and porosity, the overall cell or scaffold construct size, and the diffusion rate through the biomaterial $[17,18]$.

Improving the scaffold design will aid efficient mass transfer. For example, a laminar flow within tubular structures located within a scaffold may be beneficial for the generation of large TE constructs but requires the development of advanced bioreactor systems.

Amongst mass transfer mechanisms stated previously, oxygen transfer is a matter of the utmost importance due to poor solubility of oxygen in culture medium $[9,19,20]$. In addition, the diffusive penetration depth of oxygen within tissues in vivo is in the range of only 100 to $200 \mu \mathrm{m}$ [19]. Thus, maintaining the balance between oxygen delivery to cells and their oxygen consumption is critical, considering this diffusive distance. Therefore, the oxygen tension adjustment is a critical matter in the design process of any bioreactor [21].

In applications germane to TE, the oxygen demand will fluctuate each time. During the initial expansion phase, cell density increases with time, and consequently, the overall demand for oxygen also increases. Cells may change from a proliferative state to the state of differentiation during the later stages of the culture. This change has implications for oxygen transfer, since proliferating cells typically have a higher oxygen demand per cell than differentiating cells [2]. Therefore, during the differentiation phase, the oxygen demand is likely to decline gradually.

A culture can be aerated by one, or a combination, of the following methods: surface aeration, direct sparging, indirect and/or membrane aeration (diffusion), medium perfusion, increasing the partial pressure of oxygen, and increasing the atmospheric pressure [22]. The transport of dissolved oxygen in a bioreactor occurs in three regions as follows:

(a) bulk fluid phase of the bioreactor (global mass transfer),

(b) from the bulk to the surface of the aggregated cells (internal mass transfer),

(c) through the aggregated cells (external mass transfer).

In the first step, at the gas-liquid interface, the rate of oxygen entering the medium is limited by the relatively low solubility of oxygen in aqueous medium. The scalar concentration distributions in the vessel for the global mass transfer depend on the flow field of the vessel and the net rate of consumption or production $[23,24]$. Therefore, the oxygen concentration in the fluid experienced by the cells is a result of the balance between the oxygen delivery across the medium layer called the oxygen transfer rate (OTR) and the rate of oxygen consumption by cells named the oxygen uptake rate (OUR). Therefore, the oxygen concentration can be ten times lower as one would anticipate based on the equilibrium within the gas phase [25]. Oxygen availability has vigorous effect on cell culturing kinetics. For instance, increasing the amount of dissolved oxygen (DO) which can be done by increasing the OTR may lead to improve secondary metabolism too. The rate of OTR highly affects the liquid phase mass transfer 
coefficient $\left(k_{L} a\right)$ and, then, the productivity. Therefore, it is essential to determine the DO level in the bioreactor [24, 2628].

There are different methods for assessing the amount of oxygen delivered from the air to the culture environment (Table 2). The sulfite system is one in which transformed oxygen content from air to the aqueous solution is determined by means of the oxidation of sodium sulfite to sodium sulfate by oxygen. It could characterize the completing point of the reaction by means of a $\mathrm{pH}$ indicator, since the sulfate ions have more acidic activity than the sulfite ones. This method was applied in the presence of cobalt catalyst for determining the OTR and for studying the function of a perfusion bioreactor designed by UTLSE. It was concluded that oxygen delivery is appropriate and the bioreactor readily supplies the minimum required oxygen of the various cells. By considering the calculated OTR $\max _{\max }$ of $0.012 \mathrm{~mol} / \mathrm{L} / \mathrm{hr}$ and the largest $k_{L} a=0.02 \mathrm{~L} / \mathrm{s}$, calculations showed that bioreactor supplies the required oxygen of culturing more than $10^{10} \mathrm{CHO}$ cells in the $80 \mathrm{~mL}$ culturing volume [29].

2.2. Mechanical Stimulation. The field of TE gradually recognizes the importance of mechanical stimuli (e.g., mechanical compression, mechanical stretch, hydrodynamic pressure, and fluid flow) in the maturation of organs [5]. Mechanical stimulation is one of particular interest for musculoskeletal tissue engineering, cartilage formation, and cardiovascular tissues [30-35]. Mechanical interactions during tissue growth, between different components, that is, cells, water, and scaffold material, can determine whether cells form cell aggregates or disperse throughout the scaffold [36-38]. Selection of optimal physical parameters is complicated by a variety of cell types, scaffolds, forces, applied regimes, and culture medium available.

Cells in aggregates are exposed to higher shear stresses than single cells due to their large particle diameter [39]. It is widely accepted that shear stress has a dominant impact on tissue function and viability. Different values are reported for the maximal sustainable shear stress for different types of cells $[40,41]$. Indeed, high shear stress on the surface of the scaffold, caused by a flow of fluid, can peel off attached cells and in this condition, tissue growth is significantly slower compared with static cultures.

Simply, orientation and function of the cells is affected by fluid flow shear stress. Shear stress is a particular interesting stimulus for mammalian cell cultures because many cell types are responsive to shear stress [42-45]. For instance, it was observed that shear stress affected endothelial cell proliferation and oriented them toward flow direction [31]. There are many qualitative means for investigating fluid flow, which are summarized in Table 3.

In addition, the secretion of biological factors by stem cells can be increased by biomechanical forces. Therefore, it is important to acquire an understanding of the mechanisms by which hemodynamic forces are detected and converted into a sequence of biological responses within the cells [46]. For instance, changes in pressure or shear stress induce the rapid release of nitric oxide (NO) from the vascular endothelium [47-49]. Studies at UTLSE in a simple parallel plate flow chamber showed that NO production by Human umbilical vascular endothelial cells (HUVECs) is fluid shear stress rate dependent (data not shown).

In fact, the determination of how mechanical forces can be utilized is a challenge for bioreactor design in order to reach the proper environment necessary to produce the desired tissue engineered product. Pulsatile perfusion bioreactors integrated with elastic polymeric scaffolds enhance development and differentiation of small tissue engineered blood vessels [50-53]. Furthermore, custom-designed bioreactors utilizing biaxial strain for the mechanical stimulation of skeletal tissues were developed $[54,55]$.

2.3. Electrical Stimulation. In addition to mechanical stimuli commonly arising in tissue engineering context, electrical stimulation or even combined approaches incorporating electrical/mechanical cues need to be provided in vitro for obtaining an appropriate functionality of engineered tissue. Electrical stimuli are currently mainly applied in the field of cardiac tissue engineering to regenerate the infarcted area after heart failure [56, 57]. Radisic et al. [58] showed that electrical waves in a square form with frequency of $1 \mathrm{~Hz}$ and power of $5 \mathrm{~V} / \mathrm{cm}$ can induce contractile properties in cardiac TE constructs. The disruption of regularity of ions in an electrically affected construct leads to redistribution of charge which can then alter the $\mathrm{pH}$ gradient in the media which can be used to tailor specifically enhanced cellular function [59]. Finally, electrical pacing associated with mechanical cues in the culture when applied to the electrospun cardiac constructs resulted in better alignment, elongation, and upregulation of cardiac proteins compared with static cultures [60].

\section{Comparison between Different Types of TE Bioreactors Based on Engineering Parameters}

Bioreactors that are currently widely used in TE are static and mixed flasks, rotating wall, and perfusion bioreactors. These bioreactors offer three distinct flow conditions (static, turbulent, and laminar), and hence a different rate of nutrient supply to the surface of tissue construct [24]. They also differ in mass transfer and shear stress rates experienced by the cultured cells. Table 1 compares engineering parameters of different TE bioreactors.

Although static culture is simply designed and operated, there are nutrient diffusion limitations with large constructs since both external and internal mass transfer are undertaken by diffusion $[9,11,22]$. Statically cultured constructs often have a heterogeneous structure and composition, including a necrotic central region and dense layers of viable cells encapsulating the construct outer edge [17]. This condition appears due to concentration gradients, with local depletion of nutrients and accumulation of waste materials [18].

Cell survival and assembly on many surfaces of engineered tissues can be improved by construct cultivation in stirred flask bioreactors [61-65]. Within such flasks, scaffolds 
TABLE 1: Comparison of engineering parameters in different TE bioreactors.

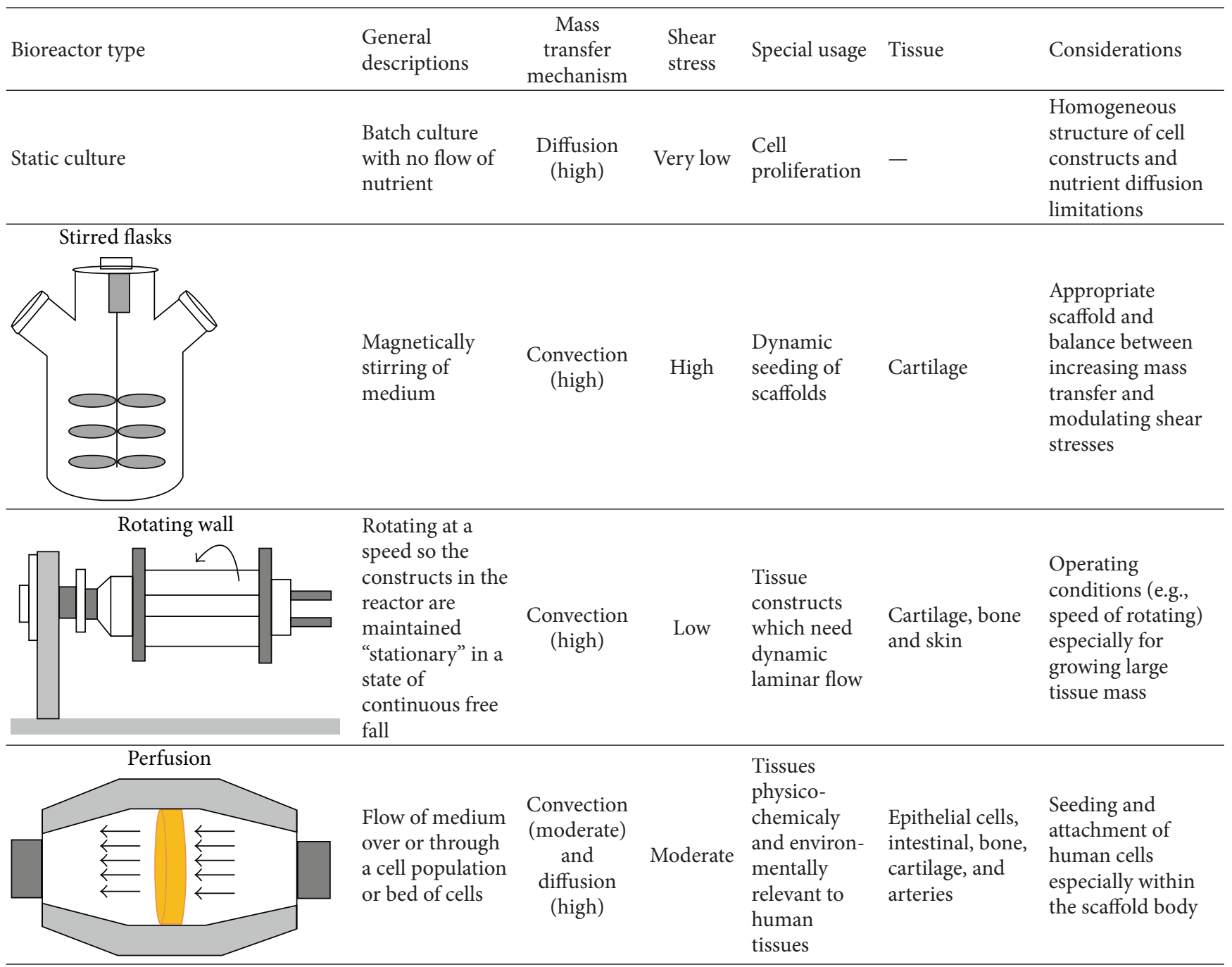

are attached to needles hanging from the lid of the flask for dynamic seeding. Convective flow, generated by a magnetic stirrer bar, allows continuous mixing of the medium surrounding the construct [24]. This environment improves nutrient diffusion and promotes cell proliferation throughout the constructs in comparison to static condition. However, the shear forces acting on the constructs are heterogeneous, which prevents homogenous tissue development [11].

In order to enhance external mass transfer under a laminar flow condition, the tissue engineered constructs can be cultivated in rotating wall bioreactors [63, 65-67]. Dynamic laminar flow of rotating bioreactors generally improves properties of the peripheral tissue layer. Also, in such bioreactors, no fibrous capsule is formed, but the limitations of the diffusional transfer of oxygen to the construct interior still remain [24]. As compared to the turbulent flow within stirred flasks, the dynamic laminar flow in rotating wall vessels contributes to reduced levels of shear stress experienced by cells on the construct. Amongst other, this aides the formation of cartilaginous tissues containing higher amounts of more uniformly distributed glycosaminoglycans (GAG) and collagen $[18,68]$.

In addition, a key point to note is that convective transfer around and through an engineered tissue at the proper flow rate can dissipate gradients of nutrients and maintain tissue mass [69]. In a novel strategy, Yu et al. [70] mixed microspheres of different densities in order to vary and modify flow velocity within a scaffold through the rotating wall bioreactor. Compared to static three-dimensional controls, culturing rat primary calvarial cells under dynamic flow conditions in a rotating system reveals a more uniform distribution of cells in the scaffold interior and also enhances phenotypic protein expression and recuperates mineralized matrix synthesis. In addition, Zhang et al. [71] recognized that scaffolds seeded by human fetal mesenchymal stem cell (hfMSC) reached cellular confluence earlier with greater cellularity and also conserved high cellular viability in the core of them compared to a static culture.

Perfusion bioreactors are used in order to force culture medium through the pores of solid porous 3D scaffolds, 


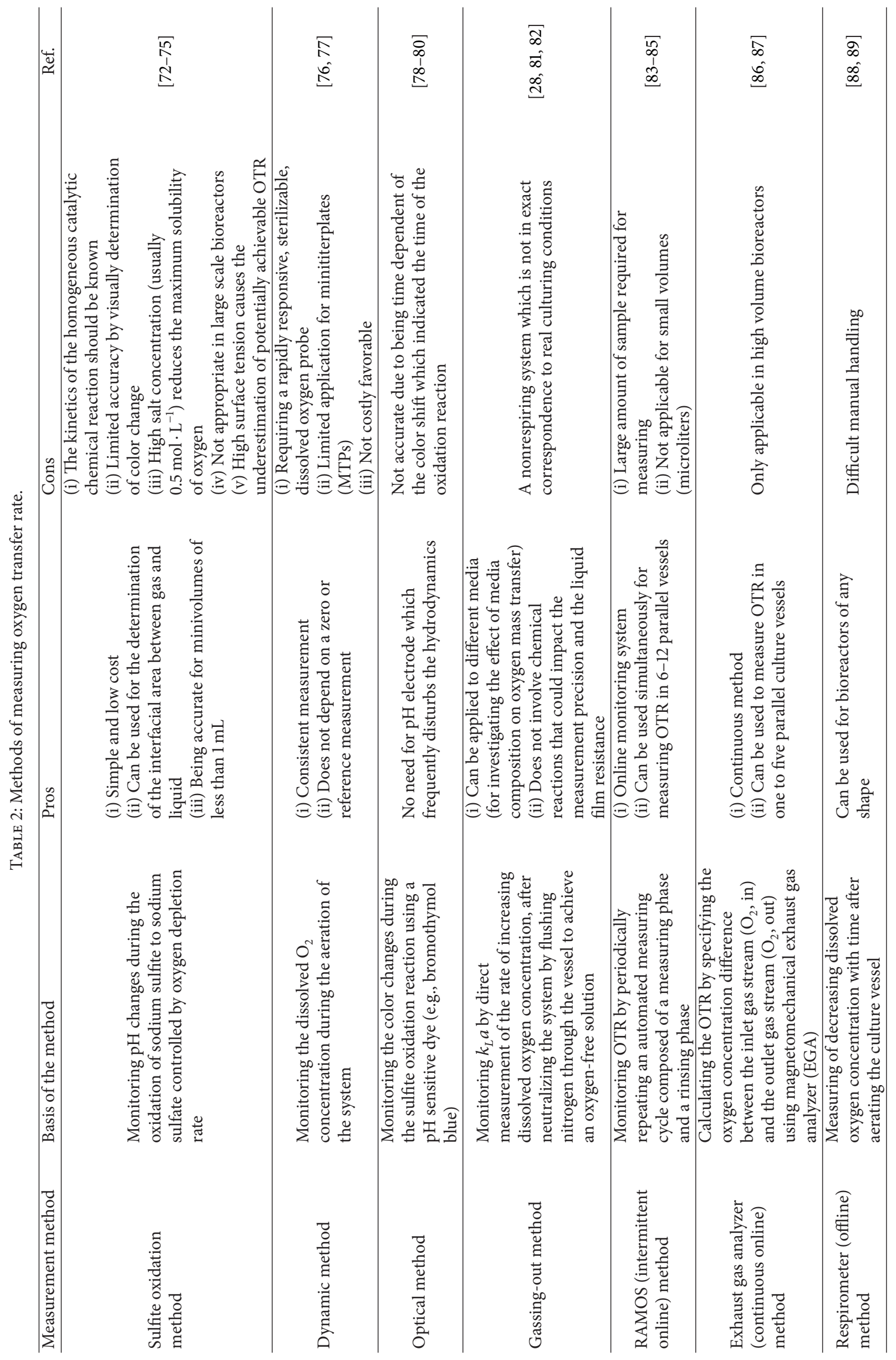




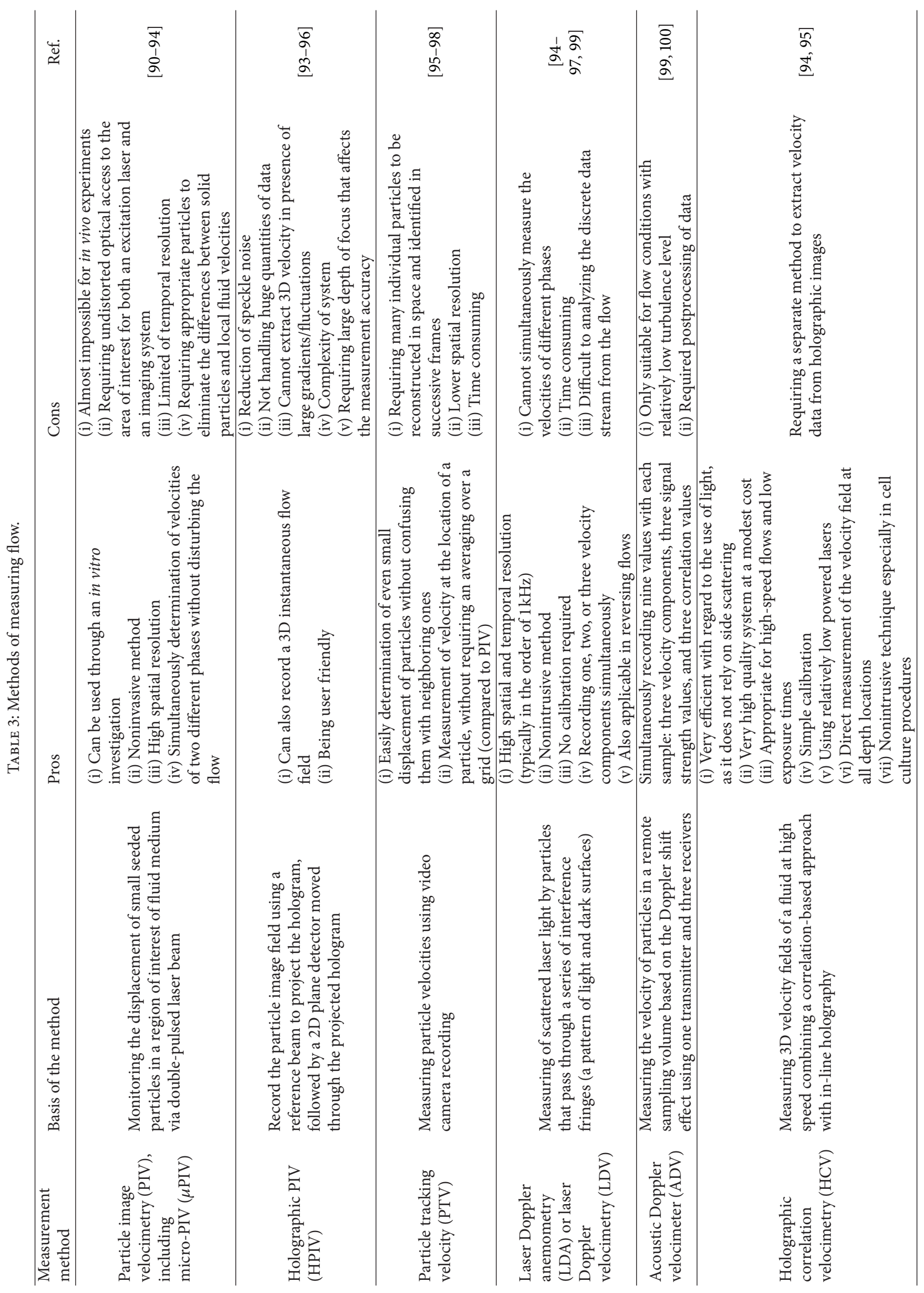


thereby enhancing nutrient transport and providing mechanical stimuli to the cells (e.g., [63, 65, 101-104]). In such systems, oxygen and nutrients are supplied to the construct interior by both diffusion and convection. The flow rate can be optimized with respect to the limiting nutrient, which is mostly oxygen due to its low solubility in culture medium [24, 105]. Perfusion of chondrocyte-seeded scaffolds was reported to elevate GAG synthesis and retention within the extracellular matrix (ECM) [106], as well as a uniform distribution of viable human chondrocytes. A perfusion system can provide a well-defined physicochemical culture environment which has great potential to generate cartilage grafts [68] or vascular grafts of clinically relevant size $[107,108]$. Bioreactors that perfuse the culture medium directly through the pores of a scaffold enhance mass transfer rate not only at the construct periphery but also within the internal pores. This can potentially eliminate mass transfer limitations. Perfusion bioreactors can offer greater control of mass transfer than other conventional systems but the potential for flow to follow a preferential path through the construct still remains a problem. This phenomenon happens particularly for scaffolds with a wide pore size distribution and nonuniformly developing tissues, leaving some regions poorly nourished, while others are perfused strongly.

It is confirmed that cartilage-like matrix synthesis by chondrocytes, chondrocyte growth, and differentiation and deposition of mineralized matrix by bone cells are enhanced by direct perfusion bioreactors [109]. It is worth to notice that the flow rate in the microenvironment of cells is to a great extent responsible for the changes of medium perfusion. Therefore, to optimize a perfusion bioreactor for tissue engineering applications, the balance between the extent of nutrient supply, the transport of metabolites to and away from cells, and the fluid-induced shear stress effects on cells located at the surface and in the porous structures of the scaffold should be considered $[17,21,105]$.

In order to gain a better understanding on how physical factors modulate tissue development, it is necessary to integrate bioreactor studies with quantitative analyses and computational modeling of changes in mass transfer and physical forces experienced by cells [17].

\section{Mathematical Modeling of Engineering Parameters}

Mathematical modeling in terms of fundamental physical and biochemical mechanisms can be used to justify experimental results and determine future research directions [110-113]. Relatively few mathematical modeling studies have focused on bioreactor culture of cell-seeded porous structures for TE $[114,115]$.

In the first stage, numerical simulation plays an important role in prediction of the global dynamic response in different parts of bioreactors. Moreover, numerical evaluation provides insight into local hydrodynamic changes in tissue constructs in order to generate quantitative anticipation of the tissue development within a bioreactor system [116]. Finally, with the aid of recently available computational tools, variables

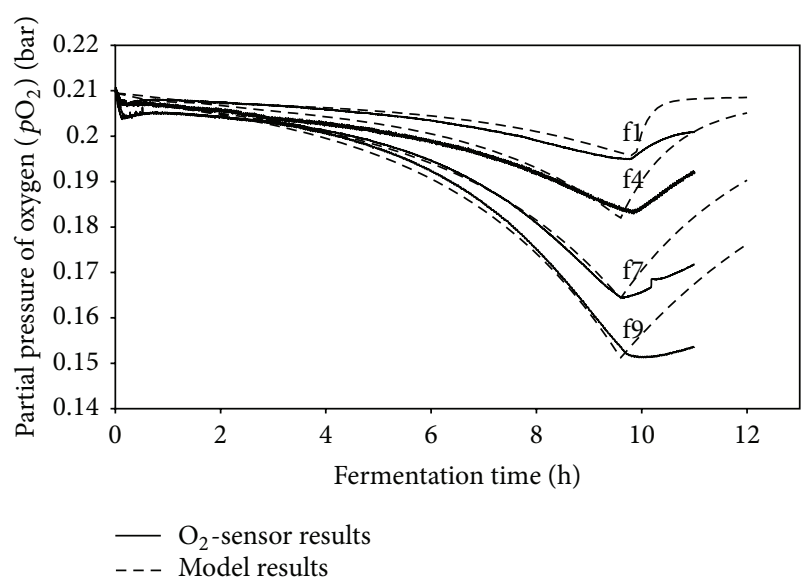

FIgure 1: Comparison between unsteady state model and experimental results for the partial pressure of oxygen in the headspace of the ventilation flasks $\mathrm{fl}, \mathrm{f} 4, \mathrm{f} 7, \mathrm{f} 9$ (sterile plug dimensions in $\mathrm{f} 1<$ $\mathrm{f} 4<\mathrm{f} 7<\mathrm{f} 9)$ is obtained for the fermentation of C. glutamicum DM 1730 on $10 \mathrm{~g} / \mathrm{L}$ glucose and $21 \mathrm{~g} / \mathrm{L}$ MOPS $\left(V_{L}=10 \mathrm{~mL}, n=400 \mathrm{rpm}\right.$, $T=30^{\circ} \mathrm{C}, d_{o}=5 \mathrm{~cm}, Y_{x / \mathrm{s}}=0.48, Y_{x / \mathrm{o}_{2}}=53 \mathrm{~g} / \mathrm{mol}, \mathrm{RQ}=1$ where $d_{o}, V_{L}, Y_{x / s}, Y_{x / o_{2}}$, and RQ are shaking diameter, filling volume, yield of biomass with respect to substrate, yield of biomass with respect to oxygen, and respiration quotient, resp.).

(e.g., flow fields of a particular bioreactor design [117, 118], incorporation of the mechanics of the scaffold material [119], and the sufficiency of bioreactor cultures [117, 120, 121], shear stresses and mass transfer in scaffold-containing bioreactors $[118,122])$ can be estimated.

As an example, Sengers et al. [3] in their review concentrated on the contribution of computational modeling as a framework to obtain an integrated understanding of key processes including nutrient transfer, matrix formation, dynamics of cell population, cell attachment and migration, and local mutual interactions between cells.

4.1. Nutrient and Mass Transfer. The amount of delivered oxygen is a significant factor in designing the cell culture bioreactors. One major obstacle preventing proper understanding of oxygen tension in TE constructs is a lack of mathematical models that can predict which parameters are beneficial for avoiding oxygen limitation and increasing oxygen diffusion across serial resistances [114, 118, 121]. This problem was resolved at UTLSE by applying traditional convective mass transfer models combined with Maxwell-Stefan diffusion mass transfer equation.

The reliability of the model can be examined by comparing the model results obtained with sulfite experiments done with four geometries of shake flasks (Figure 1).

As can be seen from Figure 1, the value for the $p \mathrm{O}_{2}$ is 0.2095 bar at the onset of the experiment. Oxygen partial pressure decreases over time as the chemical reaction proceeds. The flasks with the greater sterile plug dimensions represent lower mass transfer rates which resulted from hindered diffusion. This gives rise to a lower partial pressure of oxygen $[84,85,123,124]$. 
Yan et al. [114] developed a novel mathematical model to represent the glucose and oxygen distribution and the cell growth in a 3D cell-scaffold construct in a perfusion bioreactor. Numerical methods are employed to solve the equations involved, with a focus on investigating the effect of various factors such as culturing time, porosity, and flow rate, which are controllable in the scaffold fabrication and culturing process, on cell cultures.

Along these lines, Pisu et al. [125] proposed an improved description of oxygen consumption and GAG production by bovine chondrocytes, which is thoroughly related to cellular metabolism. The latter is simulated through appropriate population balance models which include cellular anabolic and catabolic rates.

Abdollah and Das [126] presented a general modeling framework to characterize nutrient (oxygen and glucose) transfer in a hollow fiber membrane bioreactor (HFMB) for bone tissue growth. The framework relied on solving coupled Navier-Stokes and the Maxwell-Stefan convection-diffusionreaction equations. It is indicated that due to multicomponent interactions, mass severe transfer limitations may arise severely when inlet concentration of nutrients, molecular size of the solutes, and wall membrane thickness are increased.

Rivera-Solorio and Kleis [23] used a mathematical model to investigate the local mass transfer of dissolved oxygen to the surface of freely suspended cell aggregates in a bioreactor operating in microgravity. They simulated the mass transfer in systems in which cultured cells are attached to small microcarriers in a rotating bioreactor in simulated and real microgravity.

Also, Yu et al. [127] evaluated oxygen transfer in a microbioreactor for animal cell suspension culture using the commercial software Fluent. They proposed two correlations in order to calculate the liquid-phase oxygen transfer coefficient and the minimum oxygen concentration in a microbioreactor, to provide insight into choosing the proper operating parameters in animal cell culture.

4.2. Fluid Flow. To better realize the effect of fluid flow during tissue regeneration, a number of studies using computational fluid dynamic (CFD) have been accomplished [128-134]. These CFD studies revealed detailed profile of pressure, velocity, flow fields, shear stresses, and oxygen transfer in tissue culturing chambers of various bioreactor designs. This is very useful for the design optimization of internal geometric configurations of bioreactors [116].

Lawrence et al. [16] explored the effect of reactor geometry on flow fields using the computational fluid dynamics software Comsol Multiphysics 3.4. The Brinkman equation was used to model the permeability characteristics within the chitosan porous structure. Results showed significant increase in pressure with reduction in pore size, which could limit the fluid flow and nutrient transport.

Subsequently, flow characteristics are analyzed using either Darcy's equation [135] or the Brinkman equation considered as an extension of Darcy's equation. The Brinkman equation accounts for both viscous and drag forces in the porous medium. It can be reduced to either Navier-Stokes

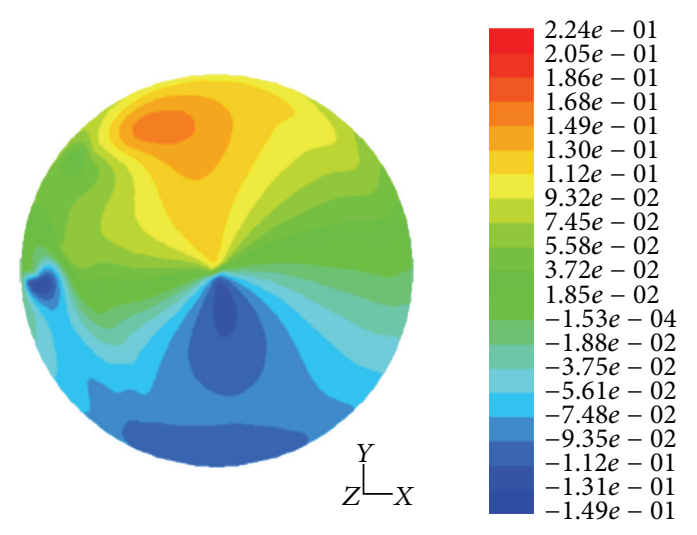

Contours of radial velocity (mixture) $(\mathrm{m} / \mathrm{s})($ time $=3.0075 e-01)$

FIGURE 2: Radial velocity distribution in a shaken 24-wells bioreactor that illustrates inhomogeneous map of radial velocity at the interface of liquid and air.

equation or Darcy's law if forces become dominant. The Brinkman equation is as follows [16]:

$$
\mu \nabla^{2} u_{s}-\frac{\mu}{k} u_{s}=\nabla p, \quad \nabla u_{s}=0,
$$

where $k$ the permeability of the porous medium, $u_{s}$ denotes the fluid superficial velocity vector, $p$ the fluid pressure, and $\mu$ is the effective viscosity in the porous medium. Nonporous sections of a bioreactor were modeled as incompressible Navier-Stokes regions. The permeability of the porous medium $(k)$ is a geometric characteristic of the porous structure at several length scales. The Navier-Stokes equation together with continuity equation provides an essential tool to investigate the mechanical behavior of fluid in shaken bioreactors.

Our research center began intensive studies of hydrodynamics applying CFD in shaken microbioreactors including 24-well plates, shaken at various shaking frequencies. For instance, schematics of the liquid phase fraction and radial velocity profiles at $0.7 \mathrm{~cm}$ distance from the bottom plane are shown in Figures 2 and 3 at shaking frequency of $200 \mathrm{rpm}$.

Output data from phase fraction simulation gave insight in the gas-liquid interfacial surface area, which then helps to determine the exact mass transfer coefficient $\left(k_{L} a\right)$ values. Furthermore, the mean radial velocity at the interface provides a guideline for obtaining wall shear stress within the entire domain of the bioreactor.

The outcomes of shear stress simulation experiments confirm that the magnitude of this mechanical quantity rarely exceeds $1 \mathrm{~Pa}$ at the bottom of the plate. This value of shear stress can be withstood by most mammalian cells [136].

In addition, a novel flow chamber was developed in our research center to assess the effect of fluid flow on the efficiency of nutrient transport and the endothelial cell stability. This chamber exhibits the major features of a standard parallel flow bioreactor in which a circular silicon scaffold is centrally located. To accomplish this, CFD was used to discretize mathematical equations. Energy dissipation rate (EDR) and 


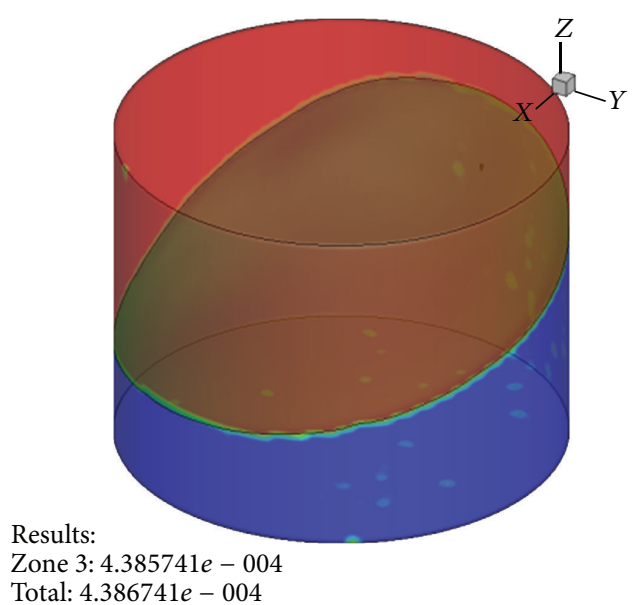

FIGURE 3: Volume fraction distribution in a shaken 24-wells bioreactor that allows accurate prediction of gas-liquid interface area within the shaking bioreactor.

shear stress were plotted versus position in the cylinder at a flow rate of $75 \mathrm{~mL} / \mathrm{min}$ (Figure 4).

For either plots of EDR and shear stress, a symmetrical pattern reveals that a homogeneous distribution of these mechanical characteristics of flow exists. However, for EDR data, some values deviate slightly between both sides of the cylinder because of a flow maldistribution which is due to a mild turbulence over the scaffold.

After completion of simulations, cell experiments were conducted for a $1 \mathrm{hr}$ period. These experiments showed that at a volumetric flow rate of $75 \mathrm{~mL} / \mathrm{min}$, the cell viability and stability are maintained, but no specific cell orientation is present (Figure 5).

In general, computational fluid dynamics applications in bioreactor development can be extended to new designs such as a novel perfusion bioreactor developed at UTLSE.

In order to assess mechanical as well as oxygen characteristics of this novel perfusion bioreactor, scientists at UTLSE used CFD to determine fluid velocity as well as pathlines features of the flow. Figure 6 further describes the computational attributes of the system.

The initial approximation of fluid flow dynamics attained with CFD is extremely beneficial in reducing time and costs of development of the bioreactor [29].

Yu et al. [137] applied a CFD model to simulate the flow and oxygen concentration fields in a microbioreactor, in which a small magnetic bar was placed in a culture well to enhance the medium mixing. It was found that the hydrodynamic environment could be appropriate for animal cell culture when the microbioreactor operated at a stirrer rotating speed of $300 \mathrm{rpm}$ and working volume of $4 \mathrm{~mL}$.

Bilgen and Barabino [138] took advantage of CFD modeling to characterize the complicated hydrodynamic environment of a wavy-walled bioreactor applied for cultivation of tissue-engineered cartilage structures. They also analyzed the changes in the flow field when TE constructs are present in the bioreactor. The flow-induced shear stress experienced by engineered constructs cultivated in the wavy walled bioreactor was much lower than that of spinner flask. The radial or axial position of the constructs can modulate this shear stress.

Lawrence et al. [16] used rectangular and circular bioreactors with three different inlet and outlet paradigms. By the use of CFD, geometries were simulated in two cases, with and without the presence of a porous structure. Residence time distribution analysis using the change of a tracer within a bioreactor revealed nonideal fluid distribution characteristics. The result represented a significant increase in pressure with a decrease in pore size, which could lead to low fluid flow and nutrient transfer limitation.

4.3. Cell Growth, Proliferation, and Viability. Chung et al. [111] developed a mathematical model for the static culture of cells grown on porous scaffolds. Results showed that the overall cell growth allows cells to spread more uniformly, while it prevents cells from competing for nutrients at the same site. They then described a mathematical model to examine the effects of medium perfusion on the cell-scaffold constructs [120]. They proposed a three-layer model, highlighting the enhancement of cell growth by medium perfusion. The model is quite detailed, involving a cell construct sandwiched between two fluid layers in order to mimic the culturing environment of direct perfusion. Although the model is valuable in developing engineered cell constructs, the enormous number of essential formulas and boundary conditions make the model cumbersome. Therefore, a compact mathematical model was to describe cell growth within a porous scaffold under direct perfusion. Neglecting the two fluid regions sandwiching the scaffold, the model contains only the scaffold region for computational purposes [110].

Shakeel [118] in his thesis developed a model which describes the key features of the tissue engineering processes such as the interaction between the cell growth, variation of material porosity, flow of fluid through the material, and delivery of nutrients to the cells. The fluid flow through the porous scaffold and the delivery of nutrients to the cells was modeled by Darcy's law and the advection-diffusion equations, respectively. For modeling the cell growth, a nonlinear reaction diffusion system was used. The results show that the distribution of cells and total cell number in the scaffold depends on the initial cell density and porosity of the scaffold.

A unique set of dynamical mathematical models was used to accurately predict metabolite and cell concentration in an aerated miniaturized shaking bioreactor at UTLSE. The major advantage of such a mathematical model is that it provides a robust tool to solve complicated oxygen transfer which unfavorably hampers metabolite production in bioprocesses.

The combination of equations which make a link between liquid phase oxygen concentration and rate of oxygen uptake with governing equations of cell concentration should be primarily solved to attain oxygen transfer rate (OTR) with respect to the course of time.

Figure 6 suggests that as the model microorganism is undergoing accelerating growth, the oxygen transfer rate increases until the growth is inhibited and consequently the OTR falls down significantly. Figure 7 illustrates the comparison between the model and experimental results for 


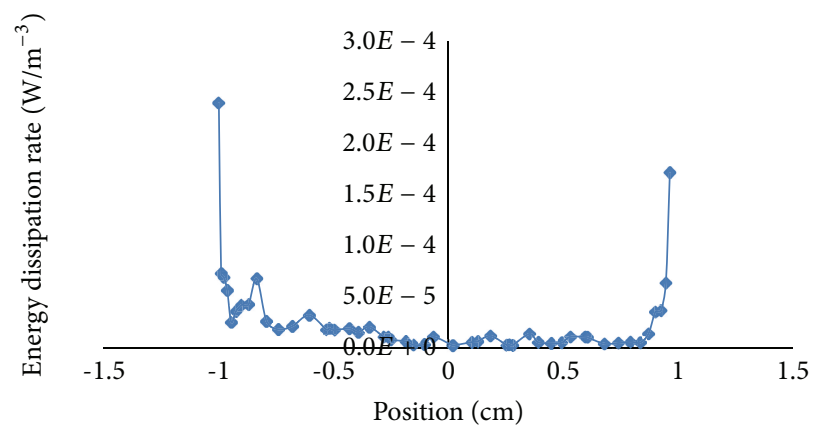

(a)

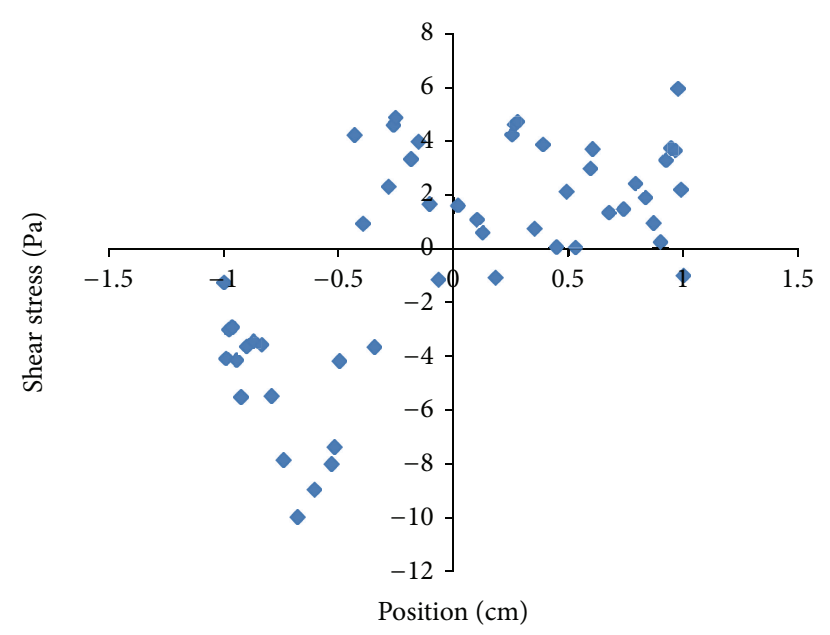

(b)

FiguRE 4: Energy dissipation rate (a) and shear stress distribution (b) versus radial position on a scaffold with radius of $1 \mathrm{~cm}$ that obviously represents safe generated shear stress on the scaffold for mammalian cell cultures.

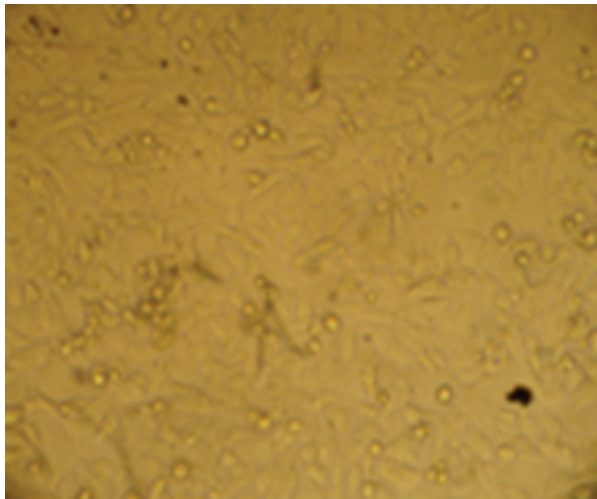

(a)

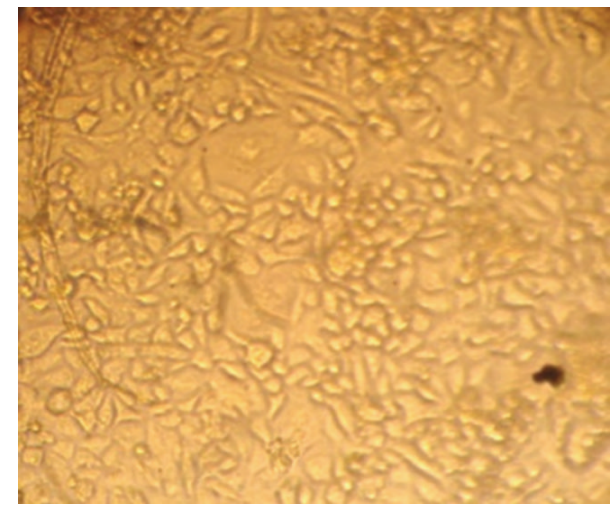

(b)

FIGURE 5: Schematics of cell morphology (a) before (b) after initiation of flow indicating flow assisted elongation of cells under continuous flow.

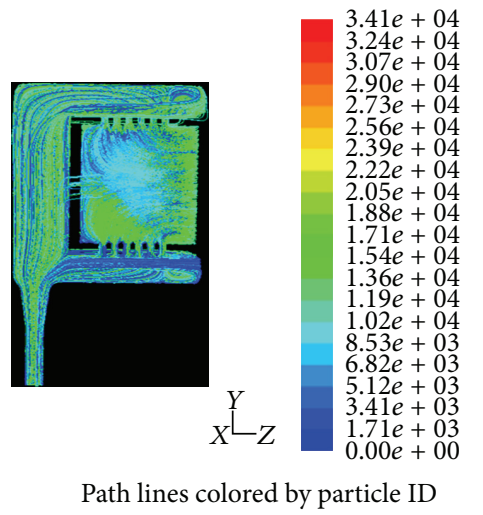

(a)

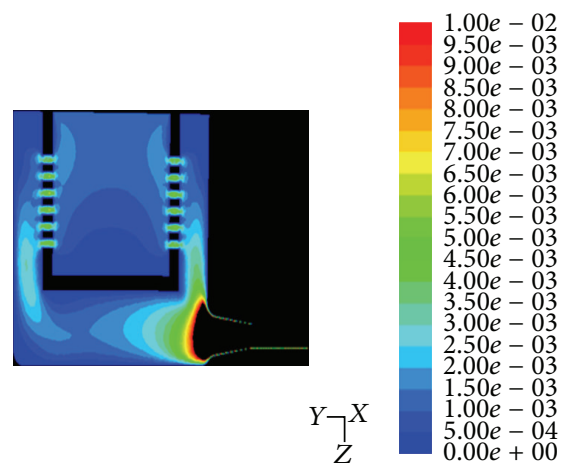

Contours of velocity magnitude $(\mathrm{m} / \mathrm{s})$

(b)

FIGURE 6: Demonstration of path lines to track the fluid particles within the bioreactor (a) and velocity magnitude to evaluate maximal shear stress in order to optimize shear stress distribution (b) in a perfusion bioreactor belonging to UTLSE. 


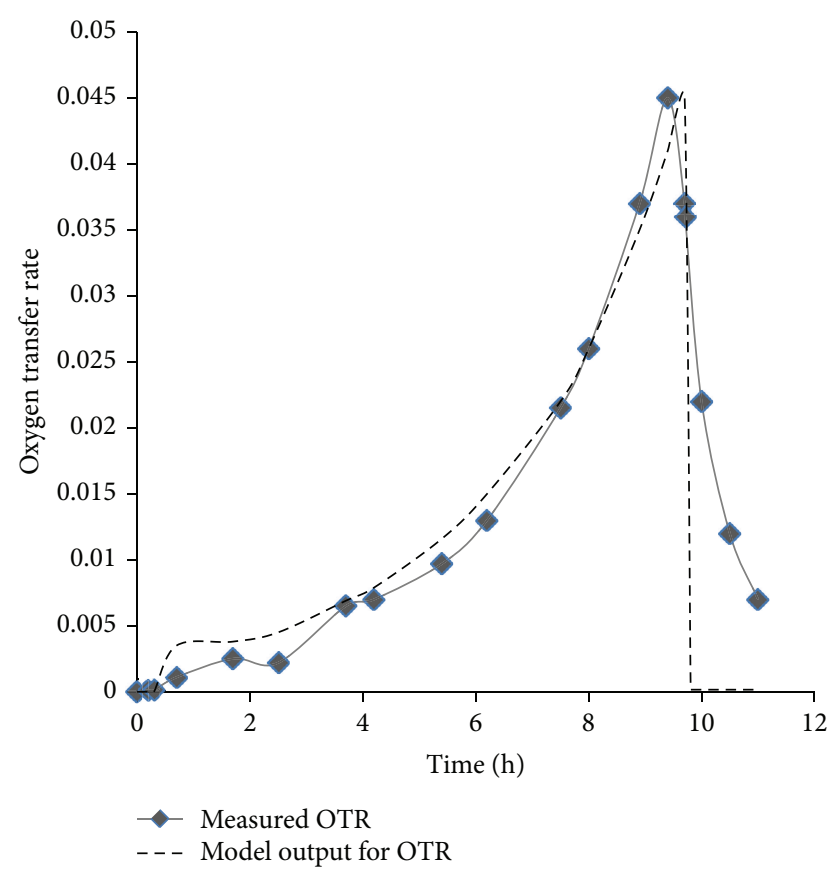

FIgURE 7: Comparison of OTR resulting from model and from experiments for a specific aerobic microorganism. The plot provides evidence of the proximity of OTR values between experimental and simulation results and of the efficacy of the simulation efforts.

a model microorganism, which suggest that a minor discrepancy between their model and the results exist [139].

\section{Conclusion}

Engineering parameters occurring in a bioreactor are of equal importance as biological parameters and should therefore be investigated thoroughly in order to optimize outcomes of TE strategies. Internal and external mass transfer (e.g., oxygen, nutrient, and waste materials transfer) as well as mechanical stimulation (e.g., fluid flow and shear stress) should be monitored online. Between different types of bioreactors, the "Perfusion Bioreactor" is the most convenient for animal cell cultures on a solid porous scaffold. Perfusion bioreactors offer both convection and diffusion and can provide nearly in vivo physiochemical and environmentally stimuli for engineered tissue constructs.

The operating conditions for diverse bioreactors can be very different per experiment. Therefore, it is essential to use mathematical equations and modeling techniques to simulate the optimal operating conditions in order to predict the best outcomes. Using the Brinkman equation along with powerful CFD codes can provide for investigating the effects of engineering parameters on the outcome of biological experiments. In this way, the efficacy of bioreactors, which is very low at present, can be optimized.

\section{Conflict of Interests}

Our researches provided in the current paper do not have any relationship with financial matters partially or completely.

\section{Acknowledgments}

The great efforts of all the students in the group of Tissue Engineering at the Department of Biomedical Engineering, UTLSE, who did an extensive research in this field, especially N. Noormohammadi, M. H. Gholami, B. Zamiri, M. Badv, Sh. Falamarzian, and P. Banikarimi are gratefully acknowledged.

\section{References}

[1] R. Pörtner, S. Nagel-Heyer, C. Goepfert, P. Adamietz, and N. M. Meenen, "Bioreactor design for tissue engineering," Journal of Bioscience and Bioengineering, vol. 100, no. 3, pp. 235-245, 2005.

[2] M. Ellis, M. Jarman-Smith, and J. B. Chaudhuri, "Bioreactor systems for tissue engineering: a four-dimensional challenge," in Bioreactors For Tissue Engineering: Principles, Design and Operation, M. Al-Rubeai and J. B. Chaudhuri, Eds., pp. 1-18, Springer, 2005.

[3] B. G. Sengers, M. Taylor, C. P. Please, and R. O. C. Oreffo, "Computational modelling of cell spreading and tissue regeneration in porous scaffolds," Biomaterials, vol. 28, no. 10, pp. 1926-1940, 2007.

[4] M. Radisic, H. Park, and G. Vunjak-Novakovic, "Cardiac-tissue engineering," in Principles of Tissue Engineering, R. Lanza, R. Langer, and J. P. Vacanti, Eds., Academic Press, 3rd edition, 2008.

[5] J. J. Pancrazio, F. Wang, and C. A. Kelley, "Enabling tools for tissue engineering," Biosensors and Bioelectronics, vol. 22, no. 12, pp. 2803-2811, 2007.

[6] R. I. Freshney, B. Obradovic, W. Grayson, C. Cannizzaro, and G. Vunjak-Novakovic, "Principles of tissue culture and bioreactor design," in Principles of Tissue Engineering, R. Lanza, R. Langer, and J. P. Vacanti, Eds., Academic Press, 3rd edition, 2008.

[7] Y. I. Yang, D. L. Seol, H. I. Kim, M. H. Cho, and S. J. Lee, "Continuous perfusion culture for generation of functional tissue-engineered soft tissues," Current Applied Physics, vol. 7, no. 1, pp. e80-e84, 2007.

[8] R. Pörtner and C. Giese, "An overview on bioreactor design, prototyping and process control for reproducible threedimensional tissue culture," in Culture of Cells For Tissue Engineering, G. Vunjack-Novakovic and R. Ian Freshney, Eds., pp. 53-78, John Wiley \& Sons, 2006.

[9] I. Martin, D. Wendt, and M. Heberer, "The role of bioreactors in tissue engineering," Trends in Biotechnology, vol. 22, no. 2, pp. 80-86, 2004.

[10] Y. Martin and P. Vermette, "Bioreactors for tissue mass culture: design, characterization, and recent advances," Biomaterials, vol. 26, no. 35, pp. 7481-7503, 2005.

[11] A. J. El Haj, M. A. Wood, P. Thomas, and Y. Yang, "Controlling cell biomechanics in orthopaedic tissue engineering and repair," Pathologie Biologie, vol. 53, no. 10, pp. 581-589, 2005.

[12] E. M. Bueno, B. Bilgen, R. L. Carrier, and G. A. Barabino, "Increased rate of chondrocyte aggregation in a wavy-walled bioreactor," Biotechnology and Bioengineering, vol. 88, no. 6, pp. 767-777, 2004.

[13] H.-C. Chen and Y.-C. Hu, "Bioreactors for tissue engineering," Biotechnology Letters, vol. 28, no. 18, pp. 1415-1423, 2006.

[14] H. Tabesh, G. Amoabediny, N. S. Nik et al., "The role of biodegradable engineered scaffolds seeded with Schwann cells for spinal cord regeneration," Neurochemistry International, vol. 54, no. 2, pp. 73-83, 2009. 
[15] R. Y. Kannan, H. J. Salacinski, K. Sales, P. Butler, and A. M. Seifalian, "The roles of tissue engineering and vascularisation in the development of micro-vascular networks: a review," Biomaterials, vol. 26, no. 14, pp. 1857-1875, 2005.

[16] B. J. Lawrence, M. Devarapalli, and S. V. Madihally, "Flow dynamics in bioreactors containing tissue engineering scaffolds," Biotechnology and Bioengineering, vol. 102, no. 3, pp. 935947, 2009.

[17] D. Wendt, N. Timmins, J. Malda, F. Janssen, A. Ratcliffe, G. Vunjak-Novakovic et al., "Bioreactors for tissue engineering," in Tissue Engineering, C. van Blitterswijk, P. Thomsen, J. Hubbell, R. Cancedda, J. D. de Bruijn, A. Lindahl et al., Eds., pp. 484-506, 2008.

[18] P. Rolfe, "Sensing in tissue bioreactors," Measurement Science and Technology, vol. 17, no. 3, pp. 578-583, 2006.

[19] G. F. Muschler, C. Nakamoto, and L. G. Griffith, "Engineering principles of clinical cell-based tissue engineering," Journal of Bone and Joint Surgery A, vol. 86, no. 7, pp. 1541-1558, 2004.

[20] S. J. Wang and J. J. Zhong, "Bioreactor engineering," in Bioprocessing For Value-Added Products From Renewable Resources, S. T. Yang, Ed., Elsevier, 2007.

[21] R. Depprich, J. Handschel, H.-P. Wiesmann, J. Jäsche-Meyer, and U. Meyer, "Use of bioreactors in maxillofacial tissue engineering," British Journal of Oral and Maxillofacial Surgery, vol. 46, no. 5, pp. 349-354, 2008.

[22] R. Eibl, D. Eibl, R. Portner, G. Catapano, and P. Czermak, Cell and Tissue Reaction Engineering, Springer, New York, NY, USA, 2008.

[23] I. Rivera-Solorio and S. J. Kleis, "Model of the mass transport to the surface of animal cells cultured in a rotating bioreactor operated in micro gravity," Biotechnology and Bioengineering, vol. 94, no. 3, pp. 495-504, 2006.

[24] J. Malda, M. Radisic, S. Levenberg et al., "Cell nutrition," in Tissue Engineering, C. van Blitterswijk, P. Thomsen, J. Hubbell et al., Eds., pp. 328-362, 2008.

[25] F. Garcia-Ochoa and E. Gomez, "Bioreactor scale-up and oxygen transfer rate in microbial processes: an overview, Biotechnology Advances, vol. 27, no. 2, pp. 153-176, 2009.

[26] R. Hermann, M. Lehmann, and J. Büchs, "Characterization of gas-liquid mass transfer phenomena in microtiter plates," Biotechnology and Bioengineering, vol. 81, no. 2, pp. 178-186, 2003.

[27] S. Suresh, V. C. Srivastava, and I. M. Mishra, “Techniques for oxygen transfer measurement in bioreactors: a review," Journal of Chemical Technology and Biotechnology, vol. 84, pp. 1091-1103, 2009.

[28] D. A. V. Marques, B. R. Torres, A. L. F. Porto, A. PessoaJúnior, and A. Converti, "Comparison of oxygen mass transfer coefficient in simple and extractive fermentation systems," Biochemical Engineering Journal, vol. 47, no. 1-3, pp. 122-126, 2009.

[29] H. Tabesh, G. Amoabediny, N. Salehi-Nik, K. Esfahani, H. Derakhshanfar, and B. Zandieh Doulabi, "Use of computerized simulation of engineering parameters in tissue-engineering bioreactors," European Spine Journal, vol. 19, Article ID 1408, 2010.

[30] A. B. Yeatts and J. P. Fisher, "Bone tissue engineering bioreactors: dynamic culture and the influence of shear stress," Bone, vol. 48, no. 2, pp. 171-181, 2011.

[31] N. Sakamoto, N. Saito, X. Han, T. Ohashi, and M. Sato, "Effect of spatial gradient in fluid shear stress on morphological changes in endothelial cells in response to flow," Biochemical and
Biophysical Research Communications, vol. 395, no. 2, pp. 264269, 2010.

[32] M. B. Simmers, A. W. Pryor, and B. R. Blackman, "Arterial shear stress regulates endothelial cell-directed migration, polarity, and morphology in confluent monolayers," The American Journal of Physiology, vol. 293, no. 3, pp. H1937-H1946, 2007.

[33] R. J. McCoy and F. J. O'Brien, "Influence of shear stress in perfusion bioreactor cultures for the development of threedimensional bone tissue constructs: a review," Tissue Engineering $B$, vol. 16, no. 6, pp. 587-601, 2010.

[34] S. D. Waldman, D. C. Couto, M. D. Grynpas, R. M. Pilliar, and R. A. Kandel, "Multi-axial mechanical stimulation of tissue engineered cartilage: review," European Cells and Materials, vol. 13, pp. 66-73, 2007.

[35] R. G. Bacabac, T. H. Smit, J. J. W. A. Van Loon, B. Z. Doulabi, M. Helder, and J. Klein-Nulend, "Bone cell responses to highfrequency vibration stress: does the nucleus oscillate within the cytoplasm?” FASEB Journal, vol. 20, no. 7, pp. 858-864, 2006.

[36] G. Lemon, J. R. King, H. M. Byrne, O. E. Jensen, and K. M. Shakesheff, "Mathematical modelling of engineered tissue growth using a multiphase porous flow mixture theory," Journal of Mathematical Biology, vol. 52, no. 5, pp. 571-594, 2006.

[37] A. Vatsa, T. H. Smit, and J. Klein-Nulend, "Extracellular NO signalling from a mechanically stimulated osteocyte," Journal of Biomechanics, vol. 40, no. 1, pp. S89-S95, 2007.

[38] R. G. Bacabac, D. Mizuno, C. F. Schmidt et al., "Round versus flat: bone cell morphology, elasticity, and mechanosensing," Journal of Biomechanics, vol. 41, pp. 1590-1598, 2008.

[39] H. J. Henzler, "Particle stress in bioreactors," Advances in Biochemical Engineering/Biotechnology, vol. 67, pp. 35-82, 2000.

[40] B. J. H. Zoro, S. Owen, R. A. L. Drake, and M. Hoare, "The impact of process stress on suspended anchorage-dependent mammalian cells as an indicator of likely challenges for regenerative medicines," Biotechnology and Bioengineering, vol. 99, no. 2, pp. 468-474, 2008.

[41] V. Bayati, Y. Sadeghi, M. A. Shokrgozar et al., “The evaluation of cyclic uniaxial strain on myogenic differentiation of adiposederived stem cells," Tissue and Cell, vol. 43, no. 6, pp. 359-366, 2011.

[42] J. Hatami, M. Tafazzoli-Shadpour, N. Haghighipour, and M. A. Shokrgozar, "Evaluation of Effects of cyclic loading on structural properties of cultured endothelial cell," Modares Journal of Medical Sciences, vol. 12, no. 4, pp. 19-30, 2010.

[43] N. Haghighipour, M. Tafazzoli-Shadpour, M. A. Shokrgozar, S. Amini, A. Amanzadeh, and M. T. Khorasani, "Topological remodeling of cultured endothelial cells by characterized cyclic strains," MCB Molecular and Cellular Biomechanics, vol. 4, no. 4, pp. 189-199, 2007.

[44] N. Haghighipour, M. Tafazzoli-Shadpour, and A. Avolio, "Residual stress distribution in a lamellar model of the arterial wall," Journal of Medical Engineering and Technology, vol. 34, no. 7-8, pp. 422-428, 2010.

[45] N. Haghighipour, M. Tafazzoli-Shadpour, M. A. Shokrgozar, and S. Amini, "Effects of cyclic stretch waveform on endothelial cell morphology using fractal analysis," Artificial Organs, vol. 34, no. 6, pp. 481-490, 2010.

[46] F. Safshekan, M. Tafazzoli Shadpour, M. A. Shokrgozar, N. Haghighipour, R. Mahdian, and A. Hemmati, "Intermittent hydrostatic pressure enhances growth factor-induced chondroinduction of human adipose-derived mesenchymal stem cells," Artificial Organs, vol. 36, no. 12, pp. 1065-1071, 2012. 
[47] A. D. Bakker, K. Soejima, J. Klein-Nulend, and E. H. Burger, "The production of nitric oxide and prostaglandin E2 by primary bone cells is shear stress dependent," Journal of Biomechanics, vol. 34, no. 5, pp. 671-677, 2001.

[48] H. ] Kaur, R. Carriveau, and B. Mutus, "A simple parallel plate flow chamber to study effects of shear stress on endothelial cells," The American Journal of Biomedical Sciences, vol. 4, no. 1, pp. 70-78, 2012.

[49] H. Kang, Y. Fan, and X. Deng, "Vascular smooth muscle cell glycocalyx modulates shear-induced proliferation, migration, and NO production responses," The American Journal of Physiology, vol. 300, no. 1, pp. H76-H83, 2011.

[50] B. C. Isenberg, C. Williams, and R. T. Tranquillo, "Smalldiameter artificial arteries engineered in vitro," Circulation Research, vol. 98, no. 1, pp. 25-35, 2006.

[51] S. E. Diamantouros, L. G. Hurtado-Aguilar, T. Schmitz-Rode, P. Mela, and S. Jockenhoevel, "Pulsatile perfusion bioreactor system for durability testing and compliance estimation of tissue engineered vascular grafts," Annals of Biomedical Engineering, 2013.

[52] M. S. Hahn, M. K. McHale, E. Wang, R. H. Schmedlen, and J. L. West, "Physiologic pulsatile flow bioreactor conditioning of poly(ethylene glycol)-based tissue engineered vascular grafts," Annals of Biomedical Engineering, vol. 35, no. 2, pp. 190-200, 2007.

[53] M. T. Zaucha, J. Raykin, W. Wan et al., "A novel cylindrical biaxial computer-controlled bioreactor and biomechanical testing device for vascular tissue engineering," Tissue Engineering A, vol. 15, no. 11, pp. 3331-3340, 2009.

[54] N. Haghighipour, S. Heidarian, M. A. Shokrgozar, and N. Amirizadeh, "Differential effects of cyclic uniaxial stretch on human mesenchymal stem cell into skeletal muscle cell," Cell Biology International, vol. 36, no. 7, pp. 669-675, 2012.

[55] M. Petrović, D. Mitraković, B. Bugarski, D. Vonwil, I. Martin, and B. Obradović, "A novel bioreactor with mechanical stimulation for skeletal tissue engineering," Chemical Industry and Chemical Engineering Quarterly, vol. 15, no. 1, pp. 41-44, 2009.

[56] N. Tandon, A. Marsano, R. Maidhof et al., "Surface-patterned electrode bioreactor for electrical stimulation," Lab on a Chip, vol. 10, no. 6, pp. 692-700, 2010.

[57] N. Tandon, A. Marsano, C. Cannizzaro, J. Voldman, and G. Vunjak-Novakovic, "Design of electrical stimulation bioreactors for cardiac tissue engineering," Proceedings of the Annual International Conference of the IEEE Engineering in Medicine and Biology Society, vol. 2008, pp. 3594-3597, 2008.

[58] M. Radisic, H. Park, H. Shing et al., "Functional assembly of engineered myocardium by electrical stimulation of cardiac myocytes cultured on scaffolds," Proceedings of the National Academy of Sciences of the United States of America, vol. 101, no. 52, pp. 18129-18134, 2004.

[59] N. Tandon, A. Marsano, R. Maidhof, L. Wan, H. Park, and G. Vunjak-Novakovic, "Optimization of electrical stimulation parameters for cardiac tissue engineering," Journal of Tissue Engineering and Regenerative Medicine, vol. 5, no. 6, pp. el15e125, 2011.

[60] I. C. Liao, J. B. Liu, N. Bursac, and K. W. Leong, "Effect of electromechanical stimulation on the maturationofmyotubes on aligned electrospun fibers," Cellular and Molecular Bioengineering, vol. 1, pp. 133-145, 2008.

[61] J. Malda, T. B. F. Woodfield, F. van der Vloodt et al., "The effect of PEGT/PBT scaffold architecture on the composition of tissue engineered cartilage," Biomaterials, vol. 26, no. 1, pp. 63-72, 2005.

[62] A. Fernandes-Platzgummer, M. M. Diogo, R. P. Baptista, C. L. D. Silva, and J. M. S. Cabral, "Scale-up of mouse embryonic stem cell expansion in stirred bioreactors," Biotechnology Progress, vol. 27, no. 5, pp. 1421-1432, 2011.

[63] S. Partap, N. A. Plunkett, and F. J. O’ Brien, “Bioreactors in tissue engineering," in Tissue Engineering, D. Eberli, Ed., pp. 323-337, 2010.

[64] A. B. Yeatts and J. P. Fisher, "Bone tissue engineering bioreactors: dynamic culture and the influence of shear stress," Bone, vol. 48, no. 2, pp. 171-181, 2011.

[65] E. Oragui, M. Nannaparaju, and W. S. Khan, "The role of bioreactors in tissue engineering for musculoskeletal applications," The Open Orthopaedics Journal, vol. 5, pp. 267-270, 2011.

[66] X. Zhang, C.-A. Bürki, M. Stettler et al., "Efficient oxygen transfer by surface aeration in shaken cylindrical containers for mammalian cell cultivation at volumetric scales up to $1000 \mathrm{~L}$," Biochemical Engineering Journal, vol. 45, no. 1, pp. 41-47, 2009.

[67] L. A. Belfiore, W. Bonani, M. Leoni, and C. J. Belfiore, "Pressuresensitive nutrient consumption via dynamic normal stress in rotational bioreactors," Biophysical Chemistry, vol. 140, no. 1-3, pp. 99-107, 2009.

[68] D. Nesic, R. Whiteside, M. Brittberg, D. Wendt, I. Martin, and P. Mainil-Varlet, "Cartilage tissue engineering for degenerative joint disease," Advanced Drug Delivery Reviews, vol. 58, no. 2, pp. 300-322, 2006.

[69] S. R. Khetani and S. N. Bhatia, "Engineering tissues for in vitro applications," Current Opinion in Biotechnology, vol. 17, no. 5, pp. 524-531, 2006.

[70] X. Yu, E. A. Botchwey, E. M. Levine, S. R. Pollack, and C. T. Laurencin, "Bioreactor-based bone tissue engineering: the influence of dynamic flow on osteoblast phenotypic expression and matrix mineralization," Proceedings of the National Academy of Sciences of the United States of America, vol. 101, no. 31, pp. 1120311208, 2004.

[71] Z.-Y. Zhang, S. H. Teoh, W.-S. Chong et al., "A biaxial rotating bioreactor for the culture of fetal mesenchymal stem cells for bone tissue engineering," Biomaterials, vol. 30, no. 14, pp. $2694-$ 2704, 2009.

[72] S. Lotter and J. Büchs, "Utilization of specific power input measurements for optimization of culture conditions in shaking flasks," Biochemical Engineering Journal, vol. 17, no. 3, pp. 195203, 2004.

[73] T. Anderlei, W. Zang, M. Papaspyrou, and J. Büchs, "Online respiration activity measurement (OTR, CTR, RQ) in shake flasks," Biochemical Engineering Journal, vol. 17, no. 3, pp. 187-194, 2004.

[74] S. A. Freyer, M. König, and A. Künkel, "Validating shaking flasks as representative screening systems," Biochemical Engineering Journal, vol. 17, no. 3, pp. 169-173, 2004.

[75] A. Akgün, C. Müller, R. Engmann, and J. Büchs, "Application of an improved continuous parallel shaken bioreactor system for three microbial model systems," Bioprocess and Biosystems Engineering, vol. 31, no. 3, pp. 193-205, 2008.

[76] M. Jamnongwong, K. Loubiere, N. Dietrich, and G. Hébrard, "Experimental study of oxygen diffusion coefficients in clean water containing salt, glucose or surfactant: consequences on the liquid-side mass transfer coefficients," Chemical Engineering Journal, vol. 165, no. 3, pp. 758-768, 2010.

[77] J. J. Bellucci and K. H. Hamaker, "Evaluation of oxygen transfer rates in stirred-tank bioreactors for clinical manufacturing," Biotechnology Progress, vol. 27, no. 2, pp. 368-376, 2011. 
[78] W. A. Duetz and B. Witholt, "Oxygen transfer by orbital shaking of square vessels and deepwell microtiter plates of various dimensions," Biochemical Engineering Journal, vol. 17, no. 3, pp. 181-185, 2004.

[79] S. D. Doig, S. C. R. Pickering, G. J. Lye, and F. Baganz, "Modelling surface aeration rates in shaken microtitre plates using dimensionless groups," Chemical Engineering Science, vol. 60, no. 10, pp. 2741-2750, 2005.

[80] P. Therning and A. Rasmuson, "Mass transfer measurements in a non-isothermal bubble column using the uncatalyzed oxidation of sulphite to sulphate," Chemical Engineering Journal, vol. 116, no. 2, pp. 97-103, 2006.

[81] D. Cascaval, A.-I. Galaction, E. Folescu, and M. Turnea, "Comparative study on the effects of $n$-dodecane addition on oxygen transfer in stirred bioreactors for simulated, bacterial and yeasts broths," Biochemical Engineering Journal, vol. 31, no. 1, pp. 5666, 2006.

[82] M. S. Puthli, V. K. Rathod, and A. B. Pandit, "Gas-liquid mass transfer studies with triple impeller system on a laboratory scale bioreactor," Biochemical Engineering Journal, vol. 23, no. 1, pp. 25-30, 2005.

[83] J. M. Seletzky, U. Noack, J. Fricke, S. Hahn, and J. Büchs, "Metabolic activity of Corynebacterium glutamicum grown on L-lactic acid under stress," Applied Microbiology and Biotechnology, vol. 72, no. 6, pp. 1297-1307, 2006.

[84] G. Amoabediny, M. P. H. Abbas, and J. Büchs, "Determination of $\mathrm{CO}_{2}$ sensitivity of micro-organisms in shaken bioreactors. II. Novel online monitoring method," Biotechnology and Applied Biochemistry, vol. 57, no. 4, pp. 167-175, 2010.

[85] G. Amoabediny and J. Büchs, "Determination of $\mathrm{CO}_{2}$ sensitivity of micro-organisms in shaken bioreactors. I. Novel method based on the resistance of sterile closure," Biotechnology and Applied Biochemistry, vol. 57, no. 4, pp. 157-166, 2010.

[86] J. M. Seletzky, U. Noack, S. Hahn, A. Knoll, G. Amoabediny, and J. Büchs, "An experimental comparison of respiration measuring techniques in fermenters and shake flasks: exhaust gas analyzer vs. RAMOS device vs. respirometer," Journal of Industrial Microbiology and Biotechnology, vol. 34, no. 2, pp. 123-130, 2007.

[87] C. Peña, C. P. Peter, J. Büchs, and E. Galindo, "Evolution of the specific power consumption and oxygen transfer rate in alginate-producing cultures of Azotobacter vinelandii conducted in shake flasks," Biochemical Engineering Journal, vol. 36, no. 2, pp. 73-80, 2007.

[88] M. Scheidle, J. Klinger, and J. Büchs, "Combination of online $\mathrm{pH}$ and oxygen transfer rate measurement in shake flasks by fiber optical technique and respiration activity monitoring system (RAMOS)," Sensors, vol. 7, pp. 3472-3480, 2007.

[89] A. R. C. Ortigara, P. Foladori, and G. Andreottola, "Kinetics of heterotrophic biomass and storage mechanism in wetland cores measured by respirometry," Water Science and Technology, vol. 64, no. 2, pp. 409-415, 2011.

[90] P. Liovic, I. D. Šutalo, R. Stewart, V. Glattauer, and L. Meagher, "Fluid flow and stresses on microcarriers in spinner flask bioreactors," in Proceedings of the 9th International Conference on CFD in the Minerals and Process Industries, Melbourne, VIC, Australia, 2012.

[91] M. Rossi, R. Lindken, P. Hierck B, and J. Westerweel, "Microfluidic system for the study of mechanical and biochemical response of endothelial cells to flow-induced mechanical stimuli," in Proceedings of the 12th Conference on Miniaturized Systems for Chemistry and Life Sciences, 2008.
[92] M. Leong Ch, A. Voorhees, and G. B. Nackman T Wei, "Flow bioreactor design for quantitative measurements over endothelial cells using micro-particle image velocimetry," Review of Scientific Instruments, vol. 84, Article ID 045109, 10 pages, 2013.

[93] C. V. Nguyen, J. Carberry, and A. Fouras, "Volumetriccorrelation PIV to measure particle concentration and velocity of microflows," Experiments in Fluids, vol. 52, no. 3, pp. 636-677, 2011.

[94] S. P. A. Higgins, C. R. Samarage, D. M. Paganin, and A. Fouras, "Holographic Correlation Velocimetry," in Proceedings of the 9th international symposium on particle image velocimetry, Kobe, Japan, 2011.

[95] M. Z. Ismadi, S. Higgins, C. R. Samarage, D. Paganin, K. Hourigan et al., "Optimisation of a stirred bioreactor through the use of a novel holographic correlation velocimetry flow measurement technique," Plos ONE, vol. 8, no. 6, Article ID e65714, 14 pages, 2013.

[96] T. Ooms, W. Koek, and J. Westerweel, "Digital holographic particle image velocimetry: eliminating a sign-ambiguity error and a bias error from the measured particle field displacement," Measurement Science and Technology, vol. 19, no. 7, Article ID 074003, 2008.

[97] N. G. Deen, B. H. Hjertager, and T. Solberg, "Comparison of PIV and LDA measurement methods applied to the gas-liquid flow in a bubble column," in Proceedings of the10th International Symposium on Applications of Laser Techniques to Fluid Mechanics, Lisbon, Portugal, 2000.

[98] Y. Feng, J. Goree, and B. Liu, "Errors in particle tracking velocimetry with high-speed cameras," Review of Scientific Instruments, vol. 82, no. 5, Article ID 053707, 2011.

[99] Z. Chara and V. Matousek, "Comparative study of ADV and LDA measuring techniques," in Proceedings of the 6th International Symposium on Ultrasonic Doppler Methods for Fluid Mechanics and Fluid Engineering.

[100] H. Chanson, M. Trevethan, and S. I. Aoki, "Acoustic Doppler velocimetry (ADV) in a small estuarine system," in IIAHR Congress, Republic of Korea, 2005.

[101] R. I. Abousleiman and V. I. Sikavitsas, "Bioreactors for tissues of the musculoskeletal system," Advances in Experimental Medicine and Biology, vol. 585, pp. 243-259, 2006.

[102] E. Cimetta, M. Flaibani, M. Mella et al., "Enhancement of viability of muscle precursor cells on 3D scaffold in a perfusion bioreactor," International Journal of Artificial Organs, vol. 30, no. 5, pp. 415-428, 2007.

[103] S. S. Kim, R. Penkala, and P. Abrahimi, "A perfusion bioreactor for intestinal tissue engineering," Journal of Surgical Research, vol. 142, no. 2, pp. 327-331, 2007.

[104] V. I. Sikavitsas, G. N. Bancroft, J. J. Lemoine, M. A. K. Liebschner, M. Dauner, and A. G. Mikos, "Flow perfusion enhances the calcified matrix deposition of marrow stromal cells in biodegradable nonwoven fiber mesh scaffolds," Annals of Biomedical Engineering, vol. 33, no. 1, pp. 63-70, 2005.

[105] M. Lovett, D. Rockwood, A. Baryshyan, and D. L. Kaplan, "Simple modular bioreactors for tissue engineering: a system for characterization of oxygen gradients, human mesenchymal stem cell differentiation, and prevascularization," Tissue Engineering $C$, vol. 16, no. 6, pp. 1565-1573, 2010.

[106] C. Lee, S. Grad, M. Wimmer, and M. Alini, "The influence of mechanical stimuli on articular cartilage tissue engineering," in Topics in Tissue Engineering, N. Ashammakhi and R. L. Reis, Eds., vol. 2, pp. 1-32, 2005. 
[107] J. Cerulli, Perfusion Bioreactor for the Development of TissueEngineered Blood Vessels [Bachelor thesis], Worcester polytechnic Institute, 2011.

[108] M. Radisic, A. Marsano, R. Maidhof, Y. Wang, and G. VunjakNovakovic, "Cardiac tissue engineering using perfusion bioreactor systems," Nature Protocols, vol. 3, no. 4, pp. 719-738, 2008.

[109] U. Meyer, A. Büchter, N. Nazer, and H. P. Wiesmann, "Design and performance of a bioreactor system for mechanically promoted three-dimensional tissue engineering," British Journal of Oral and Maxillofacial Surgery, vol. 44, no. 2, pp. 134-140, 2006.

[110] C. A. Chung, C. P. Chen, T. H. Lin, and C. S. Tseng, "A compact computational model for cell construct development in perfusion culture," Biotechnology and Bioengineering, vol. 99, no. 6, pp. 1535-1541, 2008.

[111] C. A. Chung, C. W. Yang, and C. W. Chen, "Analysis of cell growth and diffusion in a scaffold for cartilage tissue engineering," Biotechnology and Bioengineering, vol. 94, no. 6, pp. 1138-1146, 2006.

[112] M. C. Lewis, B. D. MacArthur, J. Malda, G. Pettet, and C. P. Please, "Heterogeneous proliferation within engineered cartilaginous tissue: the role of oxygen tension," Biotechnology and Bioengineering, vol. 91, no. 5, pp. 607-615, 2005.

[113] J. Malda, J. Rouwkema, D. E. Martens et al., "Oxygen gradients in tissue-engineered PEGT/PBT cartilaginous constructs: measurement and modeling," Biotechnology and Bioengineering, vol. 86, no. 1, pp. 9-18, 2004.

[114] X. Yan, D. J. Bergstrom, and X. B. Chen, "Modeling of cell cultures in perfusion bioreactors," IEEE Transactions on Biomedical Engineering, vol. 59, no. 9, pp. 2568-2575, 2012.

[115] R. D. O'Dea, S. L. Waters, and H. M. Byrne, "A two-fluid model for tissue growth within a dynamic flow environment," European Journal of Applied Mathematics, vol. 19, no. 6, pp. 607-634, 2008.

[116] Y. Shi, "Numerical simulation of global hydro-dynamics in a pulsatile bioreactor for cardiovascular tissue engineering," Journal of Biomechanics, vol. 41, no. 5, pp. 953-959, 2008.

[117] P. Sucosky, D. F. Osorio, J. B. Brown, and G. P. Neitzel, "Fluid mechanics of a spinner-flask bioreactor," Biotechnology and Bioengineering, vol. 85, no. 1, pp. 34-46, 2004.

[118] M. Shakeel, Continuum modelling of cell growth andnutrient transport in a perfusion bioreactor [Ph.D. thesis], University of Nottingham, 2011.

[119] B. G. Sengers, C. C. van Donkelaar, C. W. J. Oomens, and F. P. T. Baaijens, "Computational study of culture conditions and nutrient supply in cartilage tissue engineering," Biotechnology Progress, vol. 21, no. 4, pp. 1252-1261, 2005.

[120] C. A. Chung, C. W. Chen, C. P. Chen, and C. S. Tseng, "Enhancement of cell growth in tissue-engineering constructs under direct perfusion: modeling and simulation," Biotechnology and Bioengineering, vol. 97, no. 6, pp. 1603-1616, 2007.

[121] F. Coletti, S. Macchietto, and N. Elvassore, "Mathematical modeling of three-dimensional cell cultures in perfusion bioreactors," Industrial and Engineering Chemistry Research, vol. 45, no. 24, pp. 8158-8169, 2006.

[122] R. J. Whittaker, R. Booth, R. Dyson et al., "Mathematical modelling of fibre-enhanced perfusion inside a tissue-engineering bioreactor," Journal of Theoretical Biology, vol. 256, no. 4, pp. 533-546, 2009.

[123] G. Amoabediny and J. Büchs, "Modelling and advanced understanding of unsteady-state gas transfer in shaking bioreactors," Biotechnology and Applied Biochemistry, vol. 46, no. 1, pp. 57-67, 2007.
[124] T. Anderlei, C. Mrotzek, S. Bartsch, G. Amoabediny, C. P. Peter, and J. Büchs, "New method to determine the mass transfer resistance of sterile closures for shaken bioreactors," Biotechnology and Bioengineering, vol. 98, no. 5, pp. 999-1007, 2007.

[125] M. Pisu, N. Lai, A. Cincotti, A. Concas, and G. Cao, "Modeling of engineered cartilage growth in rotating bioreactors," Chemical Engineering Science, vol. 59, no. 22-23, pp. 5035-5040, 2004.

[126] N. S. Abdullah and D. B. Das, "Modelling nutrient transport in hollow fibre membrane bioreactor for growing bone tissue with consideration of multi-component interactions," Chemical Engineering Science, vol. 62, no. 21, pp. 5821-5839, 2007.

[127] P. Yu, T. S. Lee, Y. Zeng, and H. T. Low, "A 3D analysis of oxygen transfer in a low-cost micro-bioreactor for animal cell suspension culture," Computer Methods and Programs in Biomedicine, vol. 85, no. 1, pp. 59-68, 2007.

[128] M. Cioffi, F. Boschetti, M. T. Raimondi, and G. Dubini, "Modeling evaluation of the fluid-dynamic microenvironment in tissue-engineered constructs: a micro-CT based model," Biotechnology and Bioengineering, vol. 93, no. 3, pp. 500-510, 2006.

[129] D. W. Hutmacher and H. Singh, "Computational fluid dynamics for improved bioreactor design and 3D culture," Trends in Biotechnology, vol. 26, no. 4, pp. 166-172, 2008.

[130] B. Porter, R. Zauel, H. Stockman, R. Guldberg, and D. Fyhrie, "3-D computational modeling of media flow through scaffolds in a perfusion bioreactor," Journal of Biomechanics, vol. 38, no. 3 , pp. 543-549, 2005.

[131] H. Dubey, S. K. Das, and T. Panda, "Numerical simulation of a fully baffled biological reactor: the differential circumferential averaging mixing plane approach," Biotechnology and Bioengineering, vol. 95, no. 4, pp. 754-766, 2006.

[132] H. Singh, S. A. Eng, T. T. Lim, and D. W. Hutmacher, "Flow modeling in a novel non-perfusion conical bioreactor," Biotechnology and Bioengineering, vol. 97, no. 5, pp. 1291-1299, 2007.

[133] Y. Zeng, T.-S. Lee, P. Yu, P. Roy, and H.-T. Low, "Mass transport and shear stress in a microchannel bioreactor: numerical simulation and dynamic similarity," Journal of Biomechanical Engineering, vol. 128, no. 2, pp. 185-193, 2006.

[134] C. Provin, K. Takano, Y. Sakai, T. Fujii, and R. Shirakashi, "A method for the design of 3D scaffolds for high-density cell attachment and determination of optimum perfusion culture conditions," Journal of Biomechanics, vol. 41, no. 7, pp. 14361449, 2008.

[135] F. Boschetti, M. T. Raimondi, F. Migliavacca, and G. Dubini, "Prediction of the micro-fluid dynamic environment imposed to three-dimensional engineered cell systems in bioreactors," Journal of Biomechanics, vol. 39, no. 3, pp. 418-425, 2006.

[136] B. Pouran, G. Amoabediny, S. Saghafinia, and M. P. Haji Abbas, "Characterization of interfacial hydrodynamics in a single cell of shaken microtiter plate bioreactors applying computational fluid dynamics technique," Procedia Engineering, vol. 42, pp. 924-930, 2012.

[137] P. Yu, T. S. Lee, Y. Zeng, and H. T. Low, "Fluid dynamics of a micro-bioreactor for tissue engineering," Fluid Dynamics and Materials Processing, vol. 1, pp. 235-246, 2005.

[138] B. Bilgen and G. A. Barabino, "Location of scaffolds in bioreactors modulates the hydrodynamic environment experienced by engineered tissues," Biotechnology and Bioengineering, vol. 98, no. 1, pp. 282-294, 2007.

[139] H. O. Tabrizi, G. Amoabediny, B. Moshiri et al., "Novel dynamic model for aerated shaking bioreactors," Biotechnology and Applied Biochemistry, vol. 58, no. 2, pp. 128-137, 2011. 


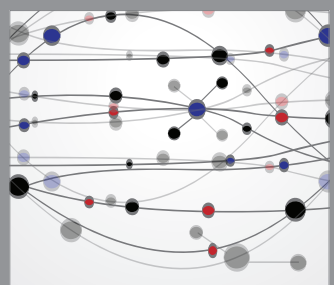

The Scientific World Journal
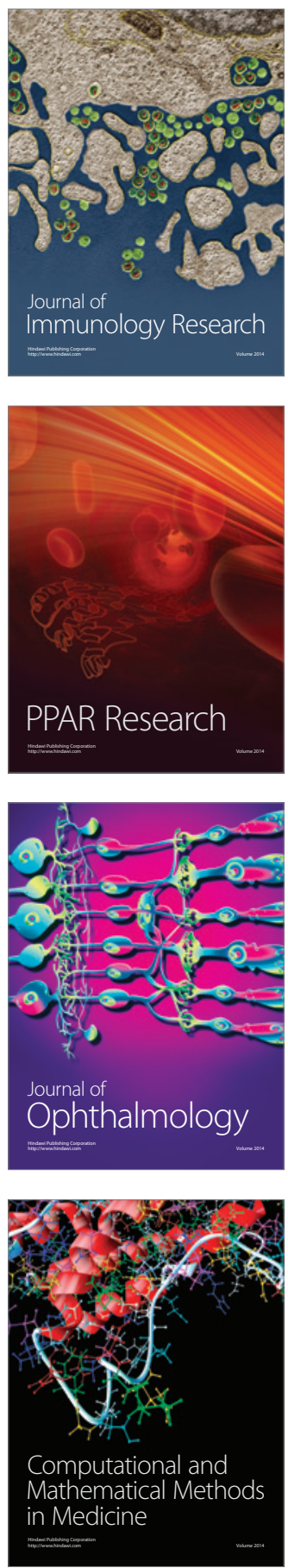

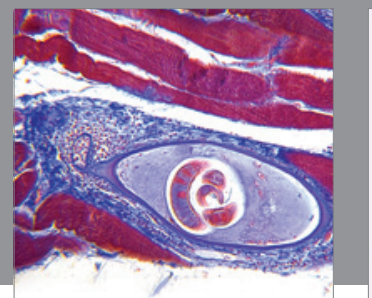

Gastroenterology

Research and Practice
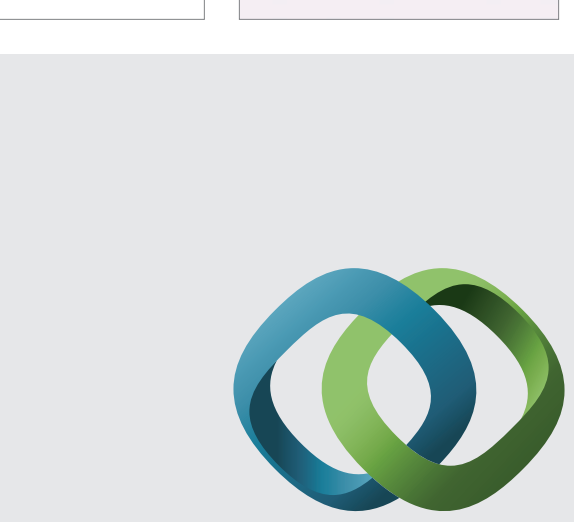

\section{Hindawi}

Submit your manuscripts at

http://www.hindawi.com
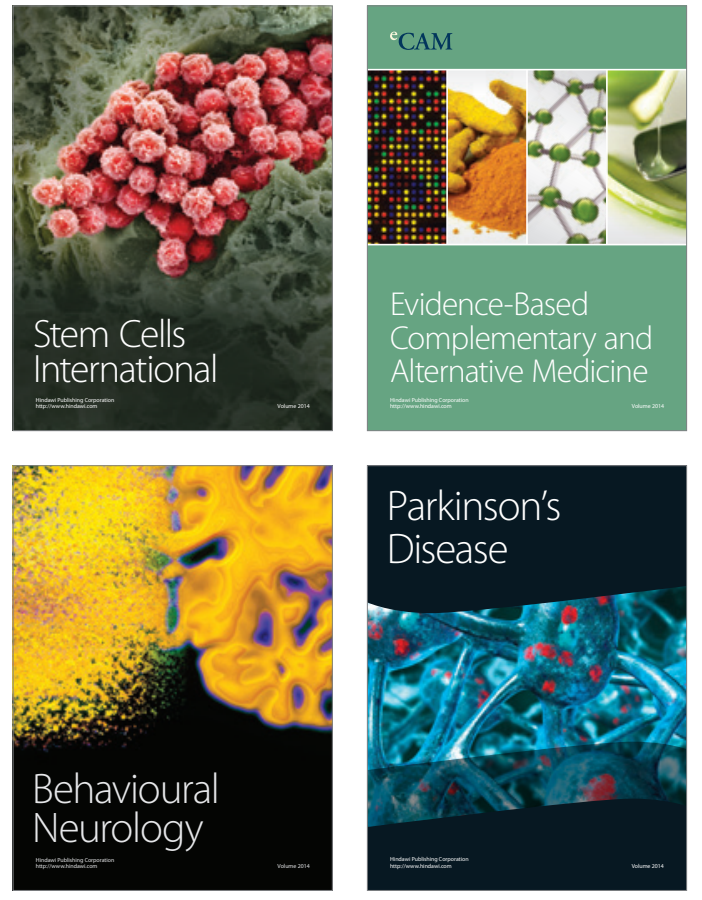
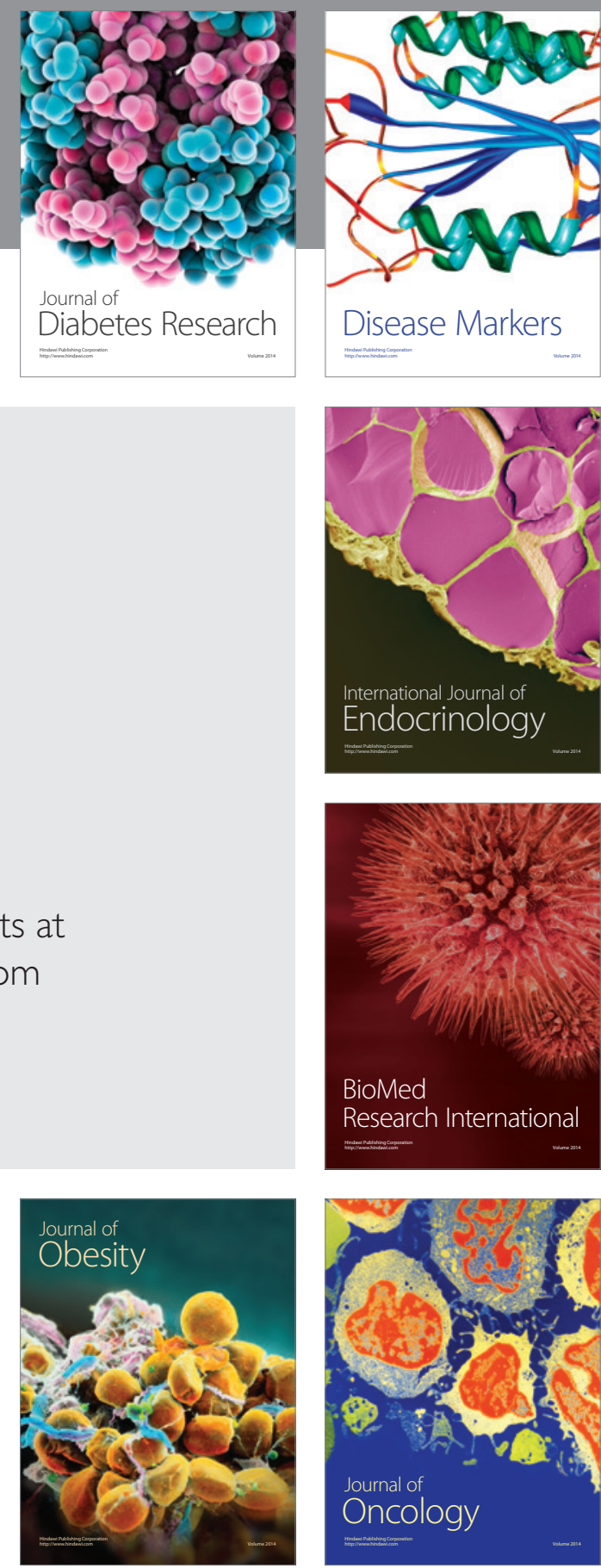

Disease Markers
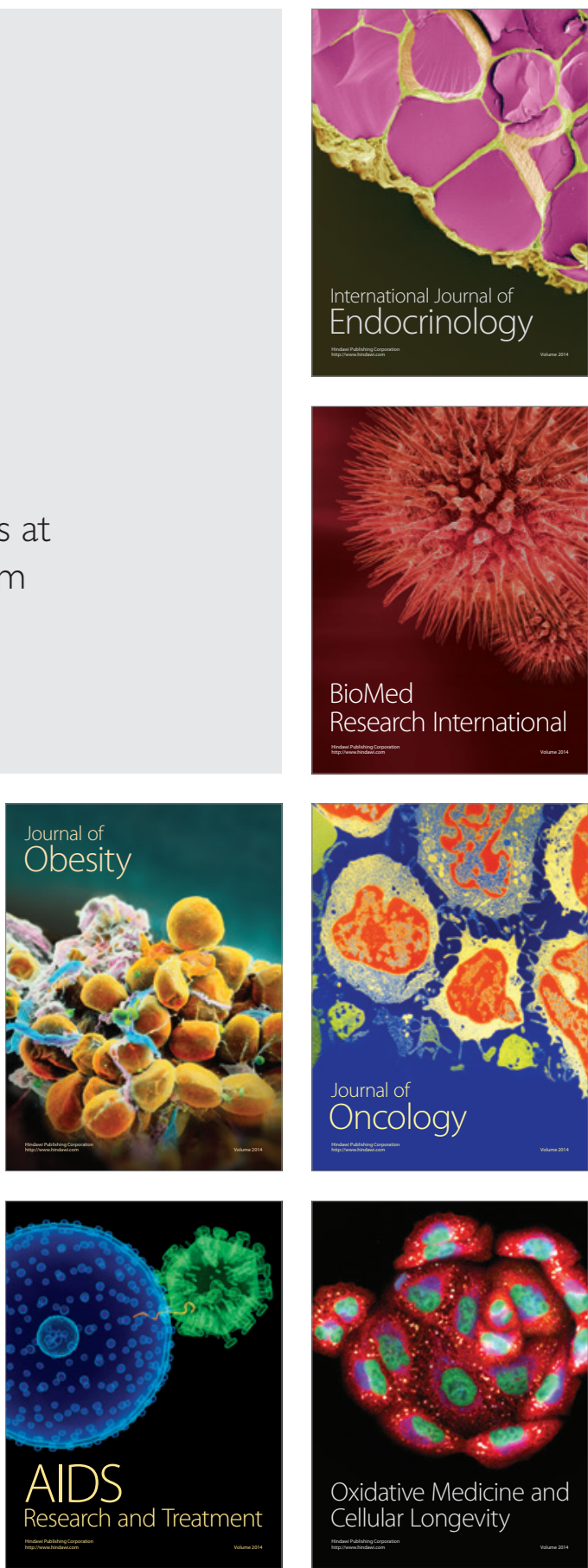